\title{
Autonomia, pós-autonomia e responsabilidade civil na prosa contemporânea: o caso Ricardo Lísias
}

\author{
Igor Ximenes Graciano* \\ A arte é uma possibilidade de resistência. \\ Ricardo Lísias, Divórcio \\ Será que a arte resiste a alguma coisa? \\ Jacques Rancière
}

\section{Sobre o adiamento de uma escrita}

Em 2013, concluída a escrita da tese de doutorado em que tratava da presença do escritor como personagem na literatura brasileira recente, li o romance Divórcio, de Ricardo Lísias, recém-lançado e já com repercussão midiática notável para um fenômeno literário. A polêmica do livro estava no risco biográfico assumido pelo autor, dadas as coincidências entre o universo da ficção e a pequena roda de pessoas que compõem os círculos jornalísticos e literários de São Paulo, que, pelas razões de nossa geopolítica, ganha uma dimensão sempre maior, tornando-se forçosamente um "caso nacional". O escândalo estava, basicamente, no "uso" de uma história privada e na "exposição" de pessoas reais, especialmente da ex-esposa do escritor.

Minha primeira leitura da obra foi de uma frustração bastante comum em quem trabalha com arte contemporânea, especialmente no âmbito da análise acadêmica, afinal, depois do ponto final da tese, surge um objeto perfeito para seu corpus. $\mathrm{Na}$ vertigem de se escrever sobre o presente, este sempre escapará, e o empenho (desejo?) teórico de vislumbrar alguma paisagem no movimento incessante da cultura está fatalmente condenado ao atraso. Minha proposta central de encontrar uma motivação estética e política para esse persistente ruído biográfico na prosa romanesca recente, assim como para o fetiche sobre a figura do escritor, encontrava na repercussão ao redor de Divórcio um elemento novo, ou pelo menos uma consequência mais intensa do problema.

Doutor em Estudos de Literatura pela Universidade Federal Fluminense (UFF) e professor de Teoria da Literatura na Universidade da Integração Internacional da Lusofonia Afro-Brasileira (Unilab), Brasil. E-mail: igor.graciano@unilab.edu.br.. 
Ainda assim, persisti com a leitura do romance e preparei uma apresentação para o Seminário sobre Literatura Brasileira Contemporânea, na Universidade de Brasília, em 2014. O título, provisório, era "Literatura política e as agruras do pequeno eu: sobre Divórcio, de Ricardo Lísias”. A intenção era de ler o romance enquanto tal, numa abordagem na medida do possível "imanente", pois já previa o embaraço de uma discussão ética, centrada na atitude do autor. A hipótese daquela abordagem, crítica ao romance, é de que havia um elo insuficiente entre o sofrimento pessoal do personagem e uma dimensão coletiva, referente ao sentido da traição e das práticas da ex-esposa como jornalista. Em resumo, Divórcio, segundo o narrador, é um romance sobre política porque sua escrita revelaria como que uma missão da literatura contra o jornalismo corporativo. Meu ponto era chamar a atenção para a fragilidade dessa tese desde o romance.

Contudo, talvez pelo estágio ainda inicial do trabalho, ou por escolhas de síntese para uma apresentação de poucos minutos, o retorno da audiência foi intenso, incomodado. Percebi que havia um problema na abordagem do livro enquanto ficção, afinal o problema moral era gritante, e ignorá-lo era ser conivente com o uso irresponsável de um pretenso relato ficcional com consequências efetivas, principalmente para a ex-esposa de Lísias. Segundo uma professora, havia relatos de que, por conta da repercussão do romance, a ex-esposa "verdadeira" tivera que se mudar do Brasil, com prejuízos para sua carreira etc. Tentei alertar que concordava com aquelas afirmações, e que meu propósito era demonstrar que, a despeito da ambiguidade que a leitura do texto estimula, a narrativa não funciona nos termos que tanto o narrador Ricardo quanto o autor Ricardo Lísias defendem: a de que se trata de um romance político. ${ }^{1}$ Foi em vão. Apesar de não pronunciada, a densidade da palavra "machista" era quase palpável nos comentários, gestos e olhares de grande parte das pessoas presentes no auditório.

Esse retorno fez com que a comunicação jamais fosse levada adiante na escrita de um artigo ou ensaio. Continuei abordando a obra de Lísias, especialmente $D i$ vórcio, em sala de aula e debates em grupos de pesquisa ou conversas informais, mas sem o ímpeto de concluir um texto. Nas aulas, percebi que tratar da obra afetava os estudantes, contudo não tanto pelos desafios teóricos que ela pudesse impor, de ordem estética e política, mas pelo voyeurismo. Em um curso de introdução aos estudos literários, um estudante disse que encontrou no Google as fotografias de casamento do Ricardo Lísias e que traria no próximo encontro da turma. Pedi que ele não o fizesse na sala, mas em outro momento, com os colegas. Percebi também que, se entre os estudantes de graduação o ruído biográfico era o que os conectava à obra, não havia, pelo menos não expressamente, qualquer veto moral ao escritor, mas uma avaliação das atitudes do personagem diante da traição: "mimado", "imaturo", "vingativo", "eu faria o mesmo" etc.

\footnotetext{
1 O narrador, ao elencar todos os argumentos de jornalistas contrários ao livro: "vai ser um livro de marido traído, então ninguém vai dar bola; sua carreira de escritor vai acabar; você por acaso está querendo ser o Paulo Coelho do adultério?; Ricardo, em 2012 ninguém tem mais paciência para livros moralistas. Ninguém pensou em política” (LísıAs, 2013, p. 192-193, grifo nosso).
} 
Em 2017, em um Colóquio na Universidade Federal da Bahia, novamente faço uma comunicação sobre Lísias, dessa vez considerando suas estratégias como autor. Como se tratava de uma Colóquio do grupo de pesquisa de que faço parte, a comunicação ganhou um tom despreocupadamente crítico, no sentido de uma conversa entre amigos, a respeito de como sua obra se consolidava como arte, publicidade e participação política ao mesmo tempo. A comunicação ocorreu pela manhã e já no período da tarde do mesmo dia o próprio Lísias, com quem nunca tive qualquer contato pessoal, me procurou via rede social para comentar, de modo bastante esquivo, sobre uma "violência" que havia ocorrido. Enfim, sabendo da comunicação (e de seu caráter crítico, francamente informal a certa altura), Lísias estabeleceu um contato no sentido, logo percebi, de influenciar minha leitura. Enviou textos sobre sua obra que julgava "mais arejados". A culminância desse contato foi o envio, para meu endereço residencial, de um folheto: "Sem título: a performance do desembargador Rogério Favreto", datado de julho de 2018 (mais tarde publicado em livro pela Editora Oficina).

O episódio é um indício do empenho de Lísias na condução de sua carreira, mas demonstrou, sobretudo, dado o apelo pessoal do contato, um aspecto central de sua produção literária. Não se trata de uma ambiguidade, no sentido dado por $\mathrm{Al}$ berca (2007), entre o registro biográfico e o ficcional, ou o que Lejeune (2008) chamou de "pacto fantasmático" em romances biográficos, quando o leitor, mesmo entendendo tratar-se de um personagem, antevê a presença fantasmática do autor empírico. Mais que esse entrelugar na recepção, o que Lísias parece empreender com sua escrita (aqui entendida num sentido amplo que ultrapassa o texto) é estender a ficcionalidade para além da obra e do pacto romanesco. Uma ficcionalidade, é certo, que não é o outro da realidade, mas um de seus atributos. Em suma, se suas narrativas não estão entre o biográfico e o ficcional, e se o autor recusa qualquer relação com a vida fatual, concluímos que seu gesto busca o que chamaremos de supraficcionalidade, uma expansão além da obra.

Essa conclusão prévia, desprovida de uma análise mais aprofundada, resulta do que ainda considero um adiamento. $\mathrm{O}$ contato do autor me impeliu novamente ao silêncio, ou à não sistematização da comunicação da UFBA em um texto acabado. A razão dessa vez se encontra justamente nessa percepção prévia do que chamarei de supraficcionalidade, e que intuitivamente percebi como algo tóxico, um tipo de contaminação que se espalha pelo território dos discursos, sempre disponíveis a um olhar capaz de organizá-los em alguma ruminação romanesca, algo presente em Divórcio e outras narrativas de Lísias. Não há, sob essa supraficcionalidade, uma abordagem crítica da obra de Lísias que não seja passível de sua absorção, de maneira que somente o silêncio é capaz de conter esse ímpeto imperialista de uma escrita que, lidando com pessoas e eventos reais, sempre será ficcional. Daí a razão do adiamento: não alimentar o monstro.

Contudo, aqui já temos o início de um texto, que, como fez Hugo Achugar, começou justamente afirmando sua incapacidade em começar: "Não sei muito bem 
por onde começar. Balbucio" (2006, p. 313). Um paradoxo analítico possível somente no ensaio. Aqui, o começo é a história de um adiamento e uma suspeita: talvez não seja ainda um texto sobre Ricardo Lísias, mas de uma pergunta $a$ partir de sua obra, daquilo que ela tem provocado de forma tão eficaz: a relação entre literatura e política no contexto contemporâneo da divulgada pós-autonomia da arte. Se há um debate moderno sobre a relação entre arte e política na era da autonomia, em que a dicotomia entre arte e realidade histórica é um pressuposto, haveria um debate sobre essa relação em dias de ambiguidade ou supraficcionalidade? Podemos falar de novos pressupostos para a relação entre arte e realidade histórica? Entre personagem e sujeito empírico?

$\mathrm{Na}$ trilha desses questionamentos, outra pergunta se volta para uma noção crucial no contato entre política e arte (no caso da arte literária, entre política e ficção): a noção de responsabilidade. A responsabilidade civil, sua dimensão e consequências jurídicas, encontra na desvinculação da ficção um álibi perfeito: o narrador nunca é o autor. Entretanto, com a exploração da ambiguidade, a questão da responsabilidade parece ganhar outro viés, afinal a imagem do narrador está fantasmaticamente atrelada à pessoa do autor, conforme a noção já referida de Lejeune (2008). Será por isso o investimento crítico de Lísias para defender o que chamamos de supraficcionalidade? Será um álibi ainda possível em dias de confusão na recepção dessas narrativas? Antes de prosseguir, é importante saber que há um jogo retórico, como se percebe nessas duas citações:

Divórcio não é um livro de jornalismo, não tem fontes, não usa off, as fotos são de arquivos familiares e o autor do livro, responsável por todas as linhas, é Ricardo Lísias (Lísias, 2013, p. 196, grifo nosso).

O que faz então com que Divórcio seja um romance? Em primeiro lugar, Excelência, é normal hoje em dia que os autores misturem à trama ficcional elementos de realidade. Depois há um narrador visivelmente criado e diferente do autor. O livro foi escrito, Excelência, para justamente causar uma separação (LísıAs, 2013, p. 218).

Enquanto jogo, as duas afirmações não são excludentes, pois coexistem como partes imbricadas de uma mesma leitura que busca tensionar os protocolos tradicionais dos pactos autobiográfico e romanesco. É e não é. Até aí, conclui-se que não há nada de novo sob o sol da modernidade. O problema, acredito, está na responsabilidade. Nos trechos citados, Ricardo Lísias é responsável ao mesmo tempo que "há um narrador visivelmente criado e diferente do autor". Se, diante do jornalismo, o narrador assume sua responsabilidade, no simulacro de um julgamento, marcado pelo uso do pronome de tratamento "Excelência", próprio ao juiz de corte, esse mesmo narrador defende sua separação do autor, afirmando que esse seria o propósito do livro. 
Não sendo apenas um jogo de máscaras, tal ambivalência diz de uma negociação da arte com os limites da atuação civil dos indivíduos. Um dilema persistente da livre criação, em se tratando de arte. Resta saber se da autonomia para a pósautonomia as estratégias dessa negociação também se transformaram.

\section{Autonomia versus pós-autonomia?}

O tom de manifesto, provocativo, do ensaio de Josefina Ludmer, "Literaturas posautónomas", já pelo uso do prefixo "pós", instaura o debate a partir da dicotomia autonomia x pós-autonomia. Assumindo uma perspectiva linear, teleológica, do tempo, a crítica argentina anuncia, referindo-se a um conjunto de narrativas contemporâneas, que "é o fim das guerras, divisões e oposições tradicionais entre formas nacionais e cosmopolitas, formas do realismo ou da vanguarda, da 'literatura pura' ou da 'literatura social' ou comprometida, da literatura rural e da urbana, assim como termina a diferenciação literária entre realidade (histórica) e ficção" (LuDMER, 2007, p. 241, tradução nossa). Ou seja, com a pós-autonomia temse o fim de uma era e o anúncio da próxima.

Ao apontar para o fim da ideia de campo literário, ou sua abertura, Ludmer anuncia novas maneiras de conceber e receber os produtos literários, fora dos pressupostos de uma distinção epistemológica entre o que é próprio da arte e os demais campos. Assim, mais que uma mediação com os discursos político, histórico, publicitário etc., a arte seria concebida também a partir desses lugares, sem colocar-se como seu oposto. Para Ludmer, "o cultural e o ficcional, na era da pósautonomia, estão em sincronia e em fusão com a realidade político-econômica" (LuDMER, 2006, s.p., tradução nossa). Portanto, a diferença que sustenta a noção de autonomia cairia por terra levando consigo um habitus, ${ }^{2}$ no sentido bourdieusiano de movimentos para legitimação dos agentes dentro de um campo. Ao fundirse arte e política, o autor deve considerar um cenário que não mais resguarda artista e obra em planos sem qualquer fricção com o "real".

A questão da responsabilidade civil dos autores com o que, em suas obras, possa atentar contra uma lei ou um código de ética, parecia relativamente estável sob o estatuto da autonomia, afinal, estamos sob a cláusula de que "qualquer semelhança é mera coincidência”. A ficção, seja ela na prosa romanesca, nas narrativas cinematográficas ou na assunção de um sujeito lírico etc., a princípio, preserva o autor empírico das consequências jurídicas de sua criação, pois o que se encontra expresso na ficção sobressai como potência, jamais referindo-se diretamente à sociedade e aos indivíduos "reais". Entretanto, a longa e famosa sequência de processos judiciais sobre obras literárias desde a consagração da ideia de "arte pela arte", inclusive com textos de autores militantes da autonomia estética (Flaubert,

Conceito da teoria dos campos relacionado à mediação entre as esferas individual e social. Grosso modo, é quando o comportamento de um agente corresponde - sem ser determinado - ao conjunto de valores prestigiados na faixa a que ele pertence no campo (Bourdieu, 1983). 
Baudelaire), indica um descompasso entre a "arte pura" e sua compreensão fora dos círculos da crítica especializada.

Antes de tratar desse descompasso e suas consequências, gostaria de situar o discurso da autonomia com um texto que, por sua dicção de manifesto, aproximase da abordagem de Ludmer. Refiro-me ao ensaio A desumanização da arte, de José Ortega y Gasset, de 1925. Publicado no calor das vanguardas do século XX, no manifesto defende-se a chamada desumanização da arte, ou seja, a negação das estéticas romântica e naturalista, que trazem "uma interpretação tradicional das realidades" (Ortega y Gasset, 2005, p. 72). Para o filósofo espanhol, "estilizar é deformar o real, desrrealizar. Estilização implica desumanização. E, vice-versa, não há outra maneira de desumanizar além de estilizar. O realismo, ao contrário, convidando o artista a seguir docilmente a forma das coisas, convida-o a não ter estilo" (ORTEga y GASSET, 2005, p. 47).

Opondo realismo - entendido em sentido amplo como representação - e estilização, Ortega y Gasset ataca a verossimilhança aristotélica e sua recompensa imediata a quem frui obras de arte: o reconhecimento. $\mathrm{O}$ empenho vanguardista, mais que dirimir eventuais problemas oriundos da semelhança entre arte e mundo, almeja sobretudo eliminar a semelhança. Trata-se de uma radicalização da autonomia, a destruição da ponte entre o senso comum sobre a beleza e a criação. Não havendo semelhança e tampouco coincidência, o compromisso do artista encontra-se somente na urdidura bem sucedida do novo. Esse pressuposto crítico ainda hoje é corriqueiro acerca do que seja o propósito da arte. O teórico Luiz Costa Lima, a respeito da maçã pintada por Cézanne, afirma que ele "não só 'deforma' a maçã que comemos, mas também atua no sentido de que a 'vejamos' doutro modo" (LimA, 200o, p. 256).

Se pensarmos na recepção pública das obras, o anseio pela autonomia funciona como projeto, no sentido de se almejar essa diferença, ainda que nunca efetivamente se consiga alcançá-la. A noção de autonomia constituiu o campo literário, e sustentou suas regras e modos de recepção, porém suas prerrogativas não foram alçadas para a imaginação pública em geral. Flaubert afirmava em correspondências o desejo de escrever "um livro sobre nada, que se sustentasse de si próprio pela forma interna de seu estilo" (FLAUBERT, 2011, p. 398), mas teve que defender Madame Bovary no tribunal contra a acusação do Ministério Público francês de que a narrativa atentava contra a moral pública e os bons costumes. Como demonstra Muller (2017), ainda que a defesa tenha lembrado o caráter ficcional da personagem Emma Bovary, a não condenação do autor deu-se sobretudo devido à contra-argumentação também de caráter moral.

Dado seu "realismo" convincente, o perigo da obra, segundo a acusação apresentada pelo promotor Ernest Pinard, estava na influência que ela poderia exercer nos leitores, especialmente nas leitoras, público majoritário do gênero romanesco no século XIX. Conforme seu argumento, a narrativa ficcional é um veículo capaz de desestruturar a ordem pública, pois incentiva o comportamento adúltero. Uma 
vez que a salvaguarda da autonomia do romance não poderia, ainda, ser defendida, dado seu caráter especializado, incompreensível no debate público em meados do século XIX, a única via para a defesa foi disputar o teor dessa influência. $\mathrm{Na}$ argumentação do advogado de Flaubert, "Madame Bovary era uma obra útil, pois promovia o horror ao vício ao mostrar os efeitos negativos de uma educação inadequada" (MULLER, 2017, p. 65).

Esse descompasso da noção de arte pela arte em contraponto à recepção pública das obras indica, desde a origem da "era da autonomia", uma ambivalência nos modos de leitura. Não por acaso, Ortega y Gasset assume, em parte devido a seu caráter aristocrático, uma posição elitista quando prediz a desumanização da arte. Diante do filisteísmo inevitável do pequeno burguês, sua sede por representações do mundo, o melhor seria promover a verdadeira arte entre os indivíduos aptos a fruí-la enquanto tal. Em vez da "mensagem", da pedagogia afetiva ou política das obras - um utilitarismo que serve à esquerda e à direita no espectro ideológico -, conclama-se os que vão "à arte precisamente porque se a reconhece como farsa" (OrTEgA y GASSET, 2005, p.76).

A responsabilidade civil do escritor, portanto, nunca esteve efetivamente resguardada pela noção de autonomia, nem mesmo quando essa foi chamada à baila diante da judicialização de narrativas ficcionais. A separação entre autor e narrador, pessoa física e personagem, ficção e biografia, tem servido para o debate sobre a literatura em âmbitos especializados, mas não desresponsabiliza o autor das consequências sociais advindas da leitura das obras. A "morte do autor", assim como a ascensão de uma escritura desassombrada dos referentes, são desenvolvimentos teóricos de uma ideia de literatura que tem a linguagem não como meio, mas como única morada.

A despeito, porém, da aclamação filosófica da linguagem, os leitores continuam estabelecendo conexões, reconhecendo mundos, aprendendo lições, compartilhando experiências. Essa constatação motivou o manifesto conservador e arrependido de Todorov, A literatura em perigo, em que o ex-estruturalista, no ocaso de sua carreira, afirma o seguinte: "Hoje, se me pergunto por que amo a literatura, a resposta que me vem espontaneamente à cabeça é: porque ela me ajuda a viver" (ToDorov, 2010, p. 23). Entre cômica e piegas, essa conclusão é sintoma de um momento da crítica em que se reavalia a autonomia estética tanto para reler a tradição quanto para abordar certas narrativas do século XXI que desafiam seu estatuto. Ludmer e Lísias são figuras relevantes que atuam no centro dessas questões, enquanto provocação teórica e expressão artística.

O termo pós-autonomia tem cumprido o papel de situar esse cenário. Entretanto, a despeito do que as denominações sugerem, a pós-autonomia parece não ser o oposto da autonomia, mas um índice para outras maneiras de se jogar com as ambivalências da escrita, especialmente no que se refere à participação política e à responsabilidade autoral. 


\section{Pós-autonomia e responsabilidade civil: "tem, mas acabou"}

A expressão popular "tem, mas acabou" é um achado linguístico muito comum no trato comercial. Com essa expressão, o vendedor informa que o produto solicitado pelo cliente existe no catálogo da loja, mas que no momento não há em estoque. No dia a dia da comunicação, esse tipo de expressão normalmente cumpre seu papel, soando absurdo somente quando se detém para observar sua contradição. Em geral, o que se afirma com ela é uma potência (se não está disponível agora, este é o lugar em que você pode encontrar tal produto). Portanto, se não resolve a transação comercial, tampouco é uma negação absoluta. Equivale a uma promessa, uma expectativa.

Na pós-autonomia, a responsabilidade civil do autor ganha um viés diferente do protocolo da autonomia. No romance tradicional, confundir autor e narrador, apesar das semelhanças, é considerada uma falha na leitura. No espectro autoficcional, terreno da identidade onomástica entre autor e personagem, também seria? À época da repercussão de Divórcio, Ricardo Lísias afirmou que "a literatura não reproduz a realidade, mas cria outra realidade a partir da utilização da linguagem. Sabemos todos que a linguagem é muito limitada e muito diferente da realidade, as palavras não são as coisas. Portanto, não pode haver realidade de nenhuma ordem na ficção" (LísIAs apud FAEDRICH, 2014, p. 239).

O argumento é pela autonomia, uma reafirmação do empenho pela distinção da linguagem, pela não confusão, logo, pela não responsabilidade. O que muda é o contexto dessa afirmação. Em Madame Bovary, Flaubert diz que "Emma sou eu", ao passo que Ricardo Lísias afirma que Ricardo "não sou eu". Do século XIX ao XXI, a defesa da leitura das obras como ficção persiste. O escritor francês afirma sua materialidade como escritor para dizer que a adúltera é fruto de sua criação, enquanto Lísias se esquiva como referência para liberar a fabulação do lugar inapreensível da vida.

A dicotomia entre autonomia e pós-autonomia diz menos de uma característica intrínseca das obras do que do jogo estabelecido entre essas duas noções. Não há pós-autonomia sem autonomia. Na indistinção pós-autonômica entre história e ficção, conforme Ludmer, a marca discursiva da autonomia entra como convidada. A confusão é desejada e rejeitada. Em Divórcio, não há presença do escritor, mas há. Trata-se de uma presença encenada, um ruído biográfico, uma potência e uma promessa de reconhecimento. A negação da "realidade" na ficção é uma negação crítica, pelo autor, que se antecipa como defesa após o delito do nome próprio. Por almejar um papel político para o romance e a literatura, a auto-exposição de Lísias justifica-se para lembrar que a linguagem não é capaz de expor, pois funda outra instância de debate e responsabilidade.

É importante perceber que o embaralhamento de discursos e estratégias da pós-autonomia não se limita aos textos normalmente percebidos como artísticos. A questão da responsabilidade na relação entre arte e política diz de uma transfor- 
mação mais ampla, que ocorre também nos modos de atuação pública no século XXI. Canclini (2012, p. 20) afirma que "agora vemos que o predomínio da forma sobre a função, que antes demarcava a cena artística, caracteriza os modos de fazer política e economia”.

Para o ensaísta mexicano, a noção de simulacro se expandiu para dimensões de atuação onde antes era inadmissível, justamente em razão da responsabilidade que os agentes devem assumir em determinadas posições. No caso brasileiro, a mentira como estratégia de governantes, que se utilizam das redes sociais como um aporte para performances retóricas com objetivos nem sempre evidentes, tornouse um evento cotidiano. Em sua conta oficial no Twitter, o Presidente da República publica afirmações inadequadas para as atribuições do cargo, ou à margem da lei constitucional, para no dia seguinte ser desmentido ou ter a fala atribuída a um de seus filhos. A autoria da afirmação é relativizada, e mesmo o teor do conteúdo é desconsiderado, sem deixar, contudo, de interferir na esfera pública como indício, intenção ou cortina de fumaça.

Se, para agentes do governo, cujas palavras e ações interferem diretamente na vida das pessoas, estratégias de performance têm sido aceitas, o que resta para a arte? Segundo Canclini, na arte contemporânea, que joga com os limites da invenção e do documento, "as obras não simplesmente 'suspendem' a realidade, mas se encontram em um momento prévio, quando o real é possível, quando ainda não se desfez. As obras tratam os fatos como acontecimentos que estão a ponto de ser" (2012, p. 20). A isso Canclini chama de "iminência", isto é, em vez de uma referenciação do real a posteriori, o sentido da iminência é algo como uma expansão dos eventos, de maneira a se assumir desde sempre uma coextensividade entre o texto da obra e outras textualidades (GrACIANO, 2019). ${ }^{3}$

$\mathrm{Na}$ arte pós-autônoma, portanto, em vez do reconhecimento advindo da representação - o narrador, o alter ego, o personagem -, o que encontramos é essa coextensividade, no sentido de que as obras reiteram certa conformação das identidades contemporâneas construídas no interior das mídias e sem apelar para uma dimensão do real que as balize. Sobre isso, Boris Groys (2014, p. 15-16, tradução nossa) afirma que "parece mais legítimo pensar essas práticas artísticas como transformações radicais desde a estética até a poética, mais especificamente até a autopoética, até a produção do próprio Eu público". Não pensar a arte tanto como um problema da recepção, mas justamente como esse local de produção identitária: a persona pública que é/não é personagem, que é/não é autor.

$\mathrm{Na}$ ágora virtual, a literatura entra como um desses locais de construção do eu, porém não mais como o outro da política, da publicidade, da teoria etc. Co-

\footnotetext{
3 No artigo "Da representação ficcional à textualidade coextensiva: o caso de Machado, de Silviano Santiago", procuro contrapor a noção corriqueira, no romance moderno, de passagem ou correlação entre duas instâncias (mundo x ficção) para a de textualidade coextensiva, no sentido de um romance que se constitui pela articulação de textos, em que o narrador apresenta-se sobretudo como um leitor.
} 
extensiva a esses discursos, a escrita literária inscreve no mar sem fim das narrativas uma assinatura capaz de ter validade enquanto fonte de argumentos, mas que não necessariamente devem ser atribuídos diretamente a um autor empírico situado em uma sociedade "de fato". Afinal, ainda segundo Groys (2014, p.17, tradução nossa), "a arte não pode explicar-se completamente como manifestação do campo cultural e social 'real', porque os campos dos quais emerge e em que circulam são também artificiais. Estão formados por personas públicas desenhadas artisticamente e que, portanto, são elas mesmas criações artísticas".

O que resulta desse cenário é que a potência da ficção, o "como se" que ela promove nos termos de uma modernidade que confrontou arte e mundo, a tal ponto que nas vanguardas do século XX buscou-se desumanizar a expressão artística, isto é, abstraí-la até não coincidir com as aparências do mundo, soa anacrônico quando o próprio mundo é entendido como farsa. No século XXI, a escrita literária não se refere e tampouco retira da vida a matéria-prima para a fabulação, pois não há vida fora das fabulações.

A propósito, onde a "vida" já é construção desde sempre, o reconhecimento aristotélico não poderia estabelecer uma ponte entre a ficção e o real, mas um encontro de personas. Tudo é forma, pois não há um conteúdo objetivo, à margem do jogo. Em meio às disputas de narrativa e à profusão de imagens de si, o formalismo não se restringe à arte, conforme a posição já citada de Canclini, pois as disputas políticas são gestos de performance esvaziados de uma intenção de verdade. As aparências bastam.

Assim sendo, na era das fake news, da pós-verdade, dos robôs, do dito-pelo-nãodito, a noção de responsabilidade civil parece tão esvaziada que abrir um questionamento sobre seu lugar na literatura soa um tanto forçado ou ingênuo. E certamente é, caso se considere a literatura como mais um sintoma dessa conjuntura, não como seu contraponto.

\section{Do adiamento da escrita para a escrita de uma indecisão}

Pretendo concluir considerando brevemente a judicialização em torno dos cinco volumes de e-books de Delegado Tobias (2014), de Lísias, para demonstrar como a questão jurídica, em vez de ser tratada como um acidente, foi incorporada - eu diria almejada - pela supraficcionalidade de Lísias, de modo a constituir o corpo sempre aberto de sua narrativa. Em Delegado Tobias, Lísias faz um folhetim em torno de sua própria morte, novamente jogando com o ruído biográfico em torno da ficção. O quinto volume é praticamente uma "extensão do texto em rede social". Depois de ser processado por falsificação de documentos pelo Ministério Público Federal (MPF) com o Delegado Tobias, Lísias compilou os textos da repercussão na "obra" impressa Inquérito policial: família Tobias (2016), que começa justamente com o arquivamento real do caso de Delegado Tobias no MPF ("Não se deve confundir falsificação com ficção", segundo o procurador no pedido de arquivamento), 
afora as reportagens e as postagens nas redes sociais. Enquanto procedimento, na pós-autonomia a responsabilidade é abolida com argumentos da autonomia estética. Assim, ao fim e ao cabo, o que se consegue é expandir a narrativa para além da obra e promover "espetáculos de realidade", conforme Laddaga (2007).

No entanto, considerando-se o lugar dessas narrativas no debate público, questiono sobre as implicações desse jogo. Entre o fetiche biográfico (certamente voyeurístico) e a supraficcionalidade, onde o sujeito e suas proposições são tangenciados, qual seria a pedra de toque do debate ético, das políticas públicas, das garantias individuais? Ao que parece, tudo é versão, construto, espetáculo. Acredito que aquilo a que nos referimos quando dizemos "literatura" pode ter um papel central de crítica efetiva a esse cenário. A referência do narrador de Divórcio, colocada aqui em epígrafe, ao indicar a possibilidade da literatura como resistência, diz desse desejo, mas o procedimento - seja do escritor Ricardo Lísias, seja do personagem-escritor Ricardo -parece não se distanciar das práticas de uma performatividade total, esvaziada de uma ética capaz de situar uma ágora e seus atores politicamente responsáveis.

Afinal, o discurso ficcional, como potência, assim como seu outro, a "realidade", uma vez colocados em jogo, como elementos não excludentes, não poderiam ultrapassar essa performance infinita, colocá-la em perspectiva? O jogo proposto pela pós-autonomia, considerando as estratégias de um escritor como Ricardo Lísias, me parece antes uma emulação, um sintoma desse estado de coisas do que sua crítica.

Colocando-se a pergunta se a arte pode mesmo resistir a algo, Rancière argumenta que o ímpeto do artista em resistir por meio de sua expressão se sustenta pela relação paradoxal entre arte e política, de maneira que "a arte vive da tensão que a faz existir, ao mesmo tempo, em si mesma e além de si mesma” (RANCIÈrE, 2007, p. 140). Ainda segundo Rancière, a vitalidade da arte está nessa tensão, capaz de sustentar uma "política da arte e uma poética da política que não podem se unir sem se auto-suprimirem” (2007, p. 140). Portanto, frente a essa tensão entre imanência e resistência, autonomia e pós-autonomia, sobressai da prosa de Lísias um além de si que suprime sua capacidade de resistência aos discursos totalitários a que pretende se contrapor, justamente por se assemelhar a eles. Afinal, se tudo é obra, se tudo pode ser fagocitado por uma narratividade redentora, pouco resta para a especulação estética: o que não se explica, o ruído, a brecha. Há mais poética da política do que uma política da arte. A tensão em parte se dissipa.

Estas considerações e a crítica que almejam esbarram no seu limite. Não propõem, não resolvem. Antes constituem-se (ou seria melhor dizer, justificam-se) como tentativa de organização das perguntas sobre participação política e literatura. Entre tais perguntas, podemos destacar estas: é possível falar de política sem responsabilidade? É adequado cobrar responsabilidade da literatura? Se não, qual regime de discursos pode expressar e expandir nossa insujeição? Numa conjuntura em que o proclamado fim da verdade, do logocentrismo, da representação etc. 
parece não ter gerado bons frutos (ao menos para o campo das esquerdas), como defender-se da leviandade com a linguagem dos que estão no poder? Desde a supraficcionalidade, o que não é mentira? O que é verdade? Na sala de espelhos da ágora contemporânea, quem responde pela barbárie?

Em suma, o que ainda chamamos de literatura pode efetivamente resistir?

\section{Referências}

Achugar, Hugo. O outro: vínculos e desvínculos. In: Planetas sem boca: escritos efêmeros sobre arte, cultura e literatura. Belo Horizonte: Editora UFMG, 2006.

Alberca, Manuel. El pacto ambiguo: de la novela biografica a la autoficción. Madrid: Editorial Biblioteca Nueva, 2007.

Bourdieu, Pierre. Questões de sociologia. Rio de Janeiro: Marco Zero, 1983.

CANclini, Néstor García. A Sociedade sem relato: antropologia e estética da iminência. Tradução de Maria Paula Gurgel Ribeiro. São Paulo: Ed. USP, 2012.

Lima, Luiz Costa. Mímesis: desafio ao pensamento. Rio de Janeiro: Civilização Brasileira, 2000.

FAEDRICH, Anna Martins. Autoficção: do conceito teórico à prática na literatura brasileira contemporânea. 2014. Tese (Doutorado em Teoria da Literatura) - Faculdade de Letras, PUCRS, Porto Alegre, 2014. Disponível em: http://repositorio. pucrs.br/dspace/handle/10923/5746. Acesso em: 28 dez. 2019.

Flaubert, Gustave. "O fanatismo da arte" In: Uma ideia moderna de literatura: textos seminais para os estudos literários (1688-1922). Roberto Acízelo de Souza (Org.). Chapecó, SC: Argos, 2011.

Graciano, Igor. Da representação ficcional à textualidade coextensiva: o caso de Machado, de Silviano Santiago. Estudos Linguísticos e Literários, Salvador, n. 62, p. 65-75, jan./jun. 2019. Disponível em: https://portalseer.ufba.br/index.php/estudos/ article/view/28339/19093. Acesso em: 28 dez. 2019.

Groys, Boris. Volverse público: las transformaciones del arte en el ágora contemporánea. Tradução de Paola Cortés Rocca. Buenos Aires: Caja Negra, 2014.

LADDAGA, Reinaldo. Espetáculos de realidad. Buenos Aires: Beatriz Viterbo Editora, 2007.

Lejeune, Philipe. O pacto autobiográfico: de Rousseau à internet. Tradução de Jovita Maria Gerhein e Maria Inês Coimbra. Belo Horizonte: Editora UFMG, 2008.

Lísias, Ricardo. Divórcio. São Paulo: Alfaguara, 2013.

Lísısas, Ricardo. Delegado Tobias (e-book), v 1, 2, 3, 4, 5. São Paulo: E-Galáxia, 2014. 
Lísıas, Ricardo. Inquérito Policial: Família Tobias. Disponível em: http://lote42. com.br/inqueritopolicial/. Acesso em: 23 jun. 2019.

LudMER, Josefina. Literaturas postautónomas. Linkillo (cosas mias). [blog]. 18 dez. 2006. Disponível em: http://linkillo.blogspot.com/2006/12/dicen-que_18.html. Acesso em: 23 jun. 2019.

LuDMER, Josefina. Literaturas postautónomas. Ciberletras, n. 17, p. 236-244, jul. 2007. Disponível em: http://www.lehman.cuny.edu/ciberletras/documents/ ISSUE17.pdf. Acesso em: 23 jun. 2019.

Muller, Andréa Correa Paraiso. O romance no tribunal: o caso Madame Bovary. Non plus. São Paulo, v. 6, n. 12, p. 54-70, 31 dez. 2017. Disponível em: http://www. revistas.usp.br/nonplus/article/view/132389. Acesso em: 23 jun. 2019.

Ortega y Gasset, José. A desumanização da arte. Tradução de Ricardo Araújo. 5 ed. São Paulo: Cortez, 2005.

RANCIÈre, Jacques. Será que a arte resiste a alguma coisa? In: Lins, Daniel (org.). Nietzsche e Deleuze: arte e resistência. Rio de Janeiro: Forense, 2007. p. 126-140.

Todorov, Tzvedan. A literatura em perigo. Tradução de Caio Meira. 3 ed. Rio de Janeiro: Difel, 2010.

Recebido em 28 de fevereiro de 2020.

Aprovado em 11 de março de 2020.

\section{Resumo/Abstract/Resumen}

Autonomia, pós-autonomia e responsabilidade civil na prosa contemporânea: o caso Ricardo Lísias

\section{Igor Ximenes Graciano}

Na modernidade, a arte se constituiu como um campo discursivo autônomo que interfere de maneira indireta na realidade social, da qual se nutre sem nunca se confundir com ela. Por isso a expressão literária normalmente é legitimada como o outro do panfleto, pois quem fala na obra nunca é o autor, assim como o universo da ficção jamais reproduz a realidade social. Contudo, certa prosa contemporânea limítrofe que desafia a noção de autonomia, juntamente com o debate teórico acerca de uma propalada "pós-autonomia" (LudMER, 2007) ou de um "pacto ambíguo" (AlBERCA, 2007), têm colocado em questão esse lugar da arte como campo de experimentação à parte da vida dita real, de maneira a se implicar mais diretamente autor e narrador, realidade e ficção, o que parece colocar em outros termos a noção de livre criação e responsabilidade civil sobre a obra. Para a discussão, tomaremos por referência o romance Divórcio (2013) e a narrativa Delegado 
Tobias (2014), ambos de Ricardo Lísias. Nosso propósito é especular se nesse investimento na ambiguidade há uma nova estratégia discursiva capaz de substituir o paradigma moderno da autonomia ou apenas reiterá-lo.

Palavras-chave: autonomia, pós-autonomia, arte, política, responsabilidade.

\section{Autonomy, post-autonomy and civil responsibility in contemporary prose: the case of Ricardo Lísias}

\section{Igor Ximenes Graciano}

In modern times, art has become a field of autonomous discourse that indirectly affects the social reality from which it feeds, without ever being confused with it. That is why literary expression was usually legitimized as the other in the pamphlet, because whoever speaks in the work is never the author, just as the universe of fiction never reproduces the social reality. However, a certain borderline contemporary prose that challenges the notion of autonomy, together with the theoretical debate about what is called "post-autonomy" (Ludmer, 2007) or an "ambiguous pact" (ALBERCA, 2007), has called into question this place of art as a field of experimentation apart from so-called real life, in order to more directly implicate author and narrator, reality and fiction, which seems to put the notion of free creation and civil responsibility for the work in another context. In the discussion, we will reference the novel Divórcio (2013) and the narrative Delegado Tobias (2014), both by Ricardo Lísias. Our purpose is to speculate whether, in this investment in ambiguity, there is a new discursive strategy capable of replacing the modern paradigm of autonomy or whether it just reiterates it.

Keywords: autonomy, post-autonomy, art, politics, responsibility.

\section{Autonomía, postautonomía y responsabilidad civil en la prosa contempo- ránea: el caso de Ricardo Lísias}

\section{Igor Ximenes Graciano}

En los tiempos modernos el arte se ha convertido en un campo discursivo autónomo que interfiere indirectamente en la realidad social, de la que se alimenta sin confundirse nunca con ella. Es por ello que la expresión literaria es generalmente legitimada como el otro en el panfleto, porque quien habla en la obra nunca es el autor, así como el universo de ficción nunca reproduce la realidad social. Sin embargo, una cierta prosa contemporánea limítrofe que desafía la noción de autonomía, junto con el debate teórico sobre la "postautonomía" (LUDMER, 2007) o "pacto ambíguo" (AlBercA, 2007), han puesto en tela de juicio este lugar del arte como un campo de experimentación, separado de la llamada "vida real", para permanecer más directamente involucrados autor y narrador, realidad y ficción; lo que parece trasladar, en otras palabras, la noción de creación libre y responsabilidad civil sobre la obra. En esta discusión nos referiremos a la novela Divórcio (2013) y la narra- 
tiva Delegado Tobias (2014), ambos de Ricardo Lísias. Nuestro propósito es especular si en esta inversión en ambigüedad se halla una nueva estrategia discursiva capaz de reemplazar el paradigma moderno de autonomía o simplemente reiterarlo.

Palabras clave: autonomía, postautonomía, arte, política, responsabilidad. 